\title{
Indonesia di Antara Masalah Etnis Rohingya dan Etnis Uighur, 2014-2019
}

\author{
Rahmadanu Pradityo \\ Universitas Indonesia
}

\begin{abstract}
Indonesia's foreign policy during the 2014-2019 period was quite dynamic. Out of many issues, two international issues received strong reactions Indonesian society including Rohingya ethnic group issue in Myanmar and the Uighur ethnic group issue in China. Protests against these two issues occurred in two different time periods in some regions of Indonesia, demanding the government to take firm actions regarding these issues. This paper examines Indonesia's attitudes toward Rohingya ethnic group issue in Myanmar and the Uighur ethnic group issue in China based on constructivism paradigm using the theory of identity. This paper presents gaps in Indonesia's identity and interests regarding these issues which led to different attitudes in responding to those issues.
\end{abstract}

Keywords: Indonesia; Rohingya; Uighur; identity; human rights; constructivism

\begin{abstract}
Abstrak
Politik luar negeri Indonesia dalam kurun waktu 2014-2019 berjalan sangat dinamis. Namun terdapat dua permasalahan internasional yang mengundang reaksi dari elemen masyarakat Indonesia, yakni permasalahan etnis Rohingya di Myanmar dan etnis Uighur di China. Elemen masyarakat di Indonesia melakukan aksi simpatik/aksi unjuk rasa terhadap kedua permasalahan tersebut dalam dua periode waktu yang berbeda di beberapa daerah Indonesia. Oleh karena itu, hal ini mendorong Indonesia untuk bersikap terhadap kedua permasalahan tersebut. Tulisan ini mengkaji sikap Indonesia dalam merespon permasalahan etnis Rohingya di Myanmar dan etnis Uighur di China, yang menggunakan paradigma konstruktivisme, yakni teori identitas untuk membahas sikap Indonesia terhadap kedua permasalahan tersebut. Tulisan ini berpendapat bahwa terdapat perbedaan identitas dan kepentingan Indonesia terhadap kedua permasalahan tersebut mengakibatkan perbedaan sikap Indonesia dalam merespon masalah etnis Rohingya di Myanmar dan etnis Uighur di China.
\end{abstract}

Kata-kata kunci: Indonesia; Rohingya; Uighur; identitas; hak asasi manusia; konstruktivisme 


\section{Pendahuluan}

Situasi geopolitik yang terjadi di dunia internasional, membuat negaranegara tidak bisa tidak berinteraksi satu dengan lainnya. Interaksi antar aktor di dunia internasional tersebut muncul dalam berbagai bentuk seperti pertemuan, kesepakatan dan pembentukan perkumpulan atau organisasi internasional. Berdasarkan hal tersebut, Indonesia yang merupakan negara kepulauan dan berada di lokasi yang strategis di kawasan Asia Tenggara memerlukan negara lainnya dalam dunia internasional demi menjaga kepentingan nasionalnya.

Dalam konteks Indonesia, kompleksitas isu domestik (seperti demokratisasi, pembangunan ekonomi dan keamanan yang begitu rumit dan bersifat multidimensional) juga tercermin dalam politik luar negeri RI. Isu-isu tradisional seperti konflik antar negara dan perang, serta isu-isu non tradisional berupa isu terorisme, lingkungan hidup, pembangunan ekonomi, HAM dan demokratisasi berbaur dan menambah kompleksitas isu yang harus ditangani di atas, dan juga melibatkan aktor-aktor negara dan non negara yang pada gilirannya akan memengaruhi sumber kapabilitas dan instrumen politik luar negeri. Berbagai isu-isu di atas juga tidak dapat dilepaskan dari karakteristik geografis Indonesia dan perkembangan-perkembangan yang terjadi di lingkungan eksternal Indonesia (Perwita, 2007).

Permasalahan yang menjadi sorotan dari dunia internasional yang juga bersinggungan Indonesia adalah permasalahan etnis Rohingya di Myanmar. Berdasarkan Human Rights Watch, pada akhir bulan Agustus 2017, lebih dari 671.000 orang yang merupakan etnis Rohingya Muslim kabur dari negaranya untuk mengungsi ke negara lainnya (Human Rights Watch, 2019). Namun demikian, kekerasan yang dilakukan oleh militer Myanmar sudah diterima oleh etnis Rohingya sebelum tahun 2017. Hal ini terlihat dari munculnya pengungsi etnis Rohingya di perairan Indonesia pada tahun 2009 dan 2012. Kemudian gelombang migrasi pengungsi Rohingya dari perairan Aceh menjadi tidak terhentikan sejak akhir tahun 2015. Tidak hanya ke Indonesia, etnis Rohingya juga mengungsi ke Thailand dan Malaysia (Sari, 2018).

Situasi domestik Indonesia juga ikut terpengaruh akibat isu Etnis Rohingya di Myanmar. Hal ini terlihat dari adanya elemen masyarakat Indonesia yang merasa memiliki kedekatan dan persaudaraan sesama muslim merespon kejadian tersebut dengan melakukan aksi simpatik/aksi unjuk rasa di depan Kedubes Myanmar pada bulan September 2017 (Nurfuadah, 2017). Aksi unjuk rasa tidak hanya terjadi di Jakarta saja, aksi unjuk rasa juga terjadi di Jombang, Jawa Timur dan wilayah lainnya (Nuramdani, 2017). Persoalan lainnya yang muncul dan menambah dinamika permasalahan adalah adanya peristiwa pelemparan bom molotov yang juga terjadi di depan Kedubes Myanmar (Nailufar, 2017). Berdasarkan reaksi yang ditunjukkan oleh elemen masyarakat Indonesia terhadap permasalahan tersebut, maka Indonesia dituntut bersikap terhadap permasalahan etnis Rohingya di Myanmar.

Pada 29 Agustus 2017, Kementerian Luar Negeri (Kemenlu) RI sudah mengeluarkan rilis tujuh sikap Indonesia atas penyerangan di Rakhine State, Myanmar yang terdiri dari Indonesia mengecam serangan kelompok bersenjata kepada pos polisi dan fasilitas penampungan pengungsi di Maungtaw Rakhine State pada 25 Agustus 2017 yang telah mengharuskan ratusan orang mengungsi 
dan menyebabkan putaran kekerasan baru. Kedua, Indonesia juga menyesalkan jatuhnya korban, baik korban jiwa maupun luka-luka. Ketiga, Indonesia mengharapkan pemerintah Myanmar segera mengambil langkah-langkah untuk memulihkan keamanan dan memberikan perlindungan kemanusiaan secara inklusif. Keempat, Indonesia juga mendorong semua pihak segera menghentikan aksi kekerasan, berkontribusi terhadap pemulihan keamanan, serta menghormati HAM masyarakat di Rakhine State, termasuk masyarakat Muslim. Kelima, situasi di Rakhine State sangat kompleks. Kerja sama semua pemangku kepentingan diperlukan agar perdamaian, keamanan, stabilitas dan pembangunan inklusif, dapat dilakukan di Rakhine State. Keenam, situasi yang damai, aman, dan stabil di Myanmar, termasuk di Rakhine State, penting untuk mendukung terjaganya stabilitas di ASEAN dan pembangunan yang berkelanjutan di kawasan. Ketujuh, Indonesia akan lanjutkan kerja sama dengan Myanmar dalam proses rekonsiliasi, demokratisasi, dan pembangunan inklusif, termasuk upaya implementasi rekomendasi laporan Kofi Annan (Kumparan, 2017).

Sementara itu, dalam waktu yang berbeda, permasalahan etnis Uighur di China juga mendapatkan perhatian internasional. Meskipun ketegangan di Xinjiang sudah berlangsung sejak lama, tetapi pada akhir tahun 2018, isu perlakuan tidak manusiawi terhadap etnis Uighur kembali mengemuka dan menjadi perhatian dunia. Pada 2016, Chen Quanguo diangkat menjadi Sekretaris Partai Komunis China (PKC) di Xinjiang. Kebijakan yang diambil oleh Chen Quanguo saat itu, meningkatkan anggaran keamanan di wilayah Xinjiang, membangun kantor polisi, meningkatkan rekrutmen polisi, menerapkan kamera pengintai dan teknologi pemindai wajah (Cumming-Bruce, 2018).

Isu tersebut juga ikut memengaruhi situasi politik domestik di Indonesia. Aksi simpatik/aksi unjuk rasa kembali muncul di Indonesia. Beberapa organisasi massa berkumpul dan melakukan aksi unjuk rasa di depan Kedubes China, Jakarta. Faktor kedekatan antar sesama muslim mendorong elemen masyarakat dari berbagai daerah bergerak menyuarakan aspirasinya. Selain itu, massa aksi juga meminta Pemerintah Indonesia untuk bersikap terkait permasalahan Uighur di China (Wardah, 2018). Di sisi lain, dunia internasional juga menentukan sikap terhadap permasalahan tersebut yang terlihat dari Duta Besar untuk PBB dari 22 negara mengirim surat mengutuk perlakuan China terhadap etnis Uighur di Xinjiang kepada Dewan HAM PBB pada bulan Juli 2019. Negara-negara tersebut terdiri dari Australia, Austria, Belgia, Kanada, Estonia, Finlandia, Inggris, Denmark, Perancis, Jerman, Jepang, Islandia, Irlandia, Latvia, Lithuania, Luxemburg, Belanda, Selandia Baru, Norwegia, Spanyol, Swedia dan Swiss (The Guardian, 2019). Namun demikian, dukungan terhadap kebijakan China di Xinjiang juga menuai banyak dukungan dari 35 negara yang terdiri dari Algeria, Angola, Bahrain, Belarus, Bolivia, Burkina Faso, Burundi, Kamboja, Kamerun, Komoro, Kongo, Kuba, Republik Demokratik Kongo, Mesir, Eritrea, Gabon, Kuwait, Laos, Myanmar, Nigeria, Korea Utara, Oman, Pakistan, Filipina, Qatar, Russia, Arab Saudi, Somalia, Sudan Selatan, Sudan, Suriah, Tajikistan, Togo, Turkmenistan, United Arab Emirates (UAE), Venezuela dan Zimbabwe (Putz, 2019). 
Permasalahan etnis Uighur di Xinjiang juga melahirkan dua kelompok negara yang menunjukkan sikap yang berbeda di PBB, yakni mengutuk China melakukan pelanggaran HAM terhadap etnis Uighur dan mendukung China untuk melanjutkan proses dalam menangani permasalahan di Xinjiang yang berkaitan dengan kontra terorisme dan deradikalisasi. Hal ini terlihat pada 29 Oktober 2019, terdapat dua pernyataan yang berbeda yang diterima dalam diskusi Sesi Ketiga dalam Committee for the Elimination of Racial Discrimination (CERD) (Tiezzi, 2019).

Sikap Indonesia lebih bersikap abstain dengan tidak mendukung dan tidak menolak perlakuan China terhadap etnis Uighur. Hal ini juga ditegaskan kembali oleh Wakil Presiden Indonesia, Jusuf Kalla yang menyatakan bahwa Indonesia menolak adanya tindakan pelanggaran HAM, akan tetapi Indonesia tidak ingin mengintervensi permasalahan domestik negara lain, dalam hal ini China (Septiari, 2018). Akan tetapi, Indonesia memainkan peran yang berbeda dalam kedua permasalahan tersebut. Selain itu, ketika kekerasan yang dilakukan militer Myanmar terhadap etnis Rohingya terjadi, maka mengakibatkan etnis Rohingya melakukan eksodus dalam skala besar. Setidaknya Indonesia dapat memberikan bantuan kemanusiaan kepada pengungsi di dalam Bangladesh. Tetapi, kesempatan yang serupa untuk melakukan pendekatan non-konfrontasi tidak muncul dalam permasalahan di Xinjiang, China (IPAC, 2019).

Berdasarkan kajian terdahulu mengenai respon Indonesia terhadap isu etnis Rohingya di Myanmar dan isu etnis Uighur di China dapat dibagi menjadi perspektif kebijakan luar negeri, tanggung jawab untuk melindungi (Responsibility to Protect) dan hubungan bilateral. Perspektif kebijakan luar negeri memberikan pandangan bahwa kebijakan luar negeri Indonesia dipengaruhi oleh berbagai macam aspek, sehingga dapat menjelaskan perilaku Indonesia dalam merespon isu-isu tertentu (Pitsuwan, 2014; Karim, 2017; Rosyidin, 2017; Rosyidin \& Dir, 2020; Purnama, et.al, 2019; Wicaksana, 2019). Sementara itu, beberapa sarjana berpendapat bahwa Indonesia melakukan prinsip Responsibility to Protect dalam konflik etnis Rohingya di Myanmar serta memberikan perlindungan pengungsi etnis Rohingya yang mengungsi ke Indonesia (Rosyidin, 2020; Prabandari \& Adiputera, 2019). Perspektif hubungan bilateral memberikan pandangan bahwa hubungan internasional antara China dan negara-negara Asia Tenggara serta hubungan China dengan negara muslim dalam konteks hubungan bilateral dipengaruhi oleh sejarah dan budaya hubungan antara keduanya. Selain itu, hubungan bilateral dengan China juga memengaruhi respon dari negara-negara Islam terhadap isu Uighur di China (Kelemen \& Turcsányi, 2020; Stuart-Fox, 2004).

Dengan melihat kajian akademik di atas, maka belum terdapat literatur yang secara tegas membahas perbedaan sikap Indonesia dalam merespon isu Rohingya dan isu Uighur. Mengingat kedua isu tersebut ikut mewarnai kondisi politik domestik dan menuai respon dari masyarakat Indonesia dalam kurun waktu tahun 2014-2019. Dengan demikian, pertanyaan penelitian dalam tulisan ini "Mengapa sikap Indonesia berbeda dalam menanggapi permasalahan etnis Rohingya di Myanmar dan etnis Uighur di China?" Tulisan ini akan menjawab pertanyaan tersebut dengan teori identitas. Adapun sistematika penulisan tulisan ini akan terbagi menjadi empat bagian. Pertama, penjelasan singkat posisi Indonesia dalam permasalahan etnis Rohingya di Myanmar dan etnis Uighur di China. Kedua, landasan teori yang digunakan dalam tulisan ini. Ketiga, pembahasan dan analisis dari teori yang digunakan dalam tulisan ini. Keempat, kesimpulan. 


\section{Landasan Teori: Konstruktivisme}

Dalam menjawab pertanyaan penelitian di atas, maka penulis menggunakan paradigma kontruktivisme yang memandang permasalahan identitas dan kepentingan dari sebuah negara yang dibentuk bukan diterima begitu saja. Kemudian kontruktivisme melihat struktur internasional sebagai sebuah struktur sosial yang dibentuk dari norma, peraturan dan hukum. Struktur ini dapat memengaruhi identitas dan kepentingan dari agen, serta memengaruhi keputusan di dunia internasional seperti contohnya intervensi humanitarian dan larangan dari penggunaan senjata pemusnah masal. Kontruktivisme juga melihat dunia sebagai proyek atau bangunan yang selalu dalam proses konstruksi. Selain itu, konstruktivisme memikirkan dari sisi ontologis dan epistemologis dari sebuah fenomena (Viotti \& Kauppi, 2012).

Tulisan ini akan menggunakan teori identitas dari Alexander Wendt untuk membahas perbedaan sikap Indonesia terhadap permasalahan etnis Rohingya di Myanmar dan etnis Uighur di China. Wendt beranggapan bahwa identitas merupakan sebuah atribut dari aktor yang membentuk motivasi dan perilakunya. Hal ini menunjukkan bahwa identitas berada pada tingkat subjektif atau tingkat unit yang bersumber pada pemahaman dari aktor itu sendiri. Tetapi, pemahaman tersebut akan bergantung pada persamaan representasi dari aktor lain dengan dirinya. Hal ini akan membentuk intersubjektivitas atau kualitas sistemik antar aktor tersebut. Dengan demikian, identitas terbentuk dari faktor internal dan faktor eksternal (Wendt, 1999: 224).

Karakteristik dari hubungan internal dan eksternal yang beragam menyebabkan terbangunnya beberapa tipologi yang tidak sepenuhnya kompatibel satu dengan yang lainnya. Dengan demikian, Wendts membagi identitas ke dalam empat jenis, yakni identitas personal/korporat, identitas tipe/golongan, identitas peran dan identitas kolektif. Dalam identitas personal/korporat, aktor hanya boleh memiliki satu identitas saja. Identitas tersebut harus memiliki dasar material, jika membicarakan tentang manusia, maka manusia memerlukan badan. Sedangkan jika memandang negara, maka diperlukan sebuah teritori atau wilayah. Kemudian identitas tipe/golongan adalah identitas yang terkorespondensi dengan tipe rezim atau bentuk negara seperti negara kapitalis, fasis, monarki dan sebagainya. Di sisi lainnya, bentuk negara yang dilihat berdasarkan prinsip internal dari legitimasi politik. Kemudian identitas peran merupakan identitas yang berkaitan dengan aktor lain dalam struktur sosial. Hal ini menunjukkan bahwa aktor tidak dapat menetapkan identitas perannya sendiri. Identitas negara dibentuk dari pandangan negara lainnya yang kemungkinan memiliki identitas yang berbeda (Wendt, 1999).

Selanjutnya, identitas kolektif merupakan konklusi logis yang menggambarkan hubungan antara aktor dan aktor lainnya dengan cara identifikasi. Cara ini merupakan proses kognitif yang membentuk identitas tunggal dari aktor-aktor yang berinteraksi satu dengan yang lainnya (Wendt, 1999: 224-230). Identitas kolektif banyak macamnya yang ditentukan dari isu, waktu dan tempat. Hal lain yang juga memengaruhi identitas kolektif tersebut dilihat dari tingkat bilateral, regional atau global. Wendt hanya mengidentifikasi dari beberapa mekanisme kausal yang mendukung terbentuknya identitas kolektif tersebut. Ketiga jenis mekanisme yang digolongkan dari peranan kausalnya 
antara lain konteks struktural, proses sistemik dan praktik strategis. Dalam konteks struktural, struktur sistem internasional baik itu regional maupun global, membentuk interaksi yang tidak saling menghalangi atau memfasilitsi munculnya dinamika pembentukan identitas kolektif. Kontruktivisme menekankan kepada struktur intersubjektif dengan memberikan ruang untuk efek dari kemunculan dari sisi kapabilitas material. Proses sistemik yang dimaksud adalah dinamika dari konteks ekternal dari tindakan negara. Wendt membagi proses sistemik menjadi dua jenis, yakni peningkatan interdependensi dan konvergensi transnasional dari nilai-nilai domestik. Dalam praktik strategis bahwa adanya sesuatu hal yang lebih dalam interaksi strategis dibandingkan produksi dan reproduksi identitas dan kepentingan (Wendt, 1994).

Identitas merujuk kepada subjek aktor tersebut yang membentuk berbagai tipe dari keadaan aktor. Sedangkan kepentingan merujuk kepada keinginan dari aktor itu sendiri yang membentuk motivasi yang membantu untuk menjelaskan perilaku aktor. Kepentingan lahir dari identitas karena aktor tidak dapat menyadari kepentingannya sebelum mengetahui jati diri dari aktor tersebut. Selain itu, identitas dan kepentingan memiliki konten kultural yang beraneka ragam. Hal ini menunjukkan bahwa tanpa kepentingan, maka identitas tidak memiliki kekuatan motivasi dan tanpa identitas, maka kepentingan tidak memiliki arah (Wendt, 1999: 231). Selain itu, tindakan aktor juga sangat dipengaruhi oleh persepsi atau pemaknaan terhadap suatu obyek, atau aktor lain (Kusuma et.al, 2019).

\begin{tabular}{|c|c|c|}
\hline $\begin{array}{l}\text { Identitas dan } \\
\text { Kepentingan Indonesia }\end{array}$ & $\begin{array}{l}\text { Perbedaan Sikap } \\
\text { Indonesia terhadap }\end{array}$ & $\begin{array}{c}\text { Identitas dan } \\
\text { Kepentingan Indonesia }\end{array}$ \\
\hline $\begin{array}{l}\text { ternadap permasalanan } \\
\text { Rohingya di Myanmar }\end{array}$ & $\begin{array}{c}\text { permasalahan } \\
\text { Rohingya dan } \\
\text { Uighur }\end{array}$ & $\begin{array}{c}\text { permasalahan Uighur } \\
\text { di China }\end{array}$ \\
\hline
\end{tabular}

\section{Gambar 1. Alur berpikir bahwa identitas Indonesia menentukan kepentingan dan kebijakan Indonesia dalam isu Uighur dan Rohingya.}

\section{Permasalahan HAM Etnis Rohingya dan Etnis Uighur: Tinjauan Umum}

Etnis Rohingya merupakan sebuah kelompok etnis muslim yang berasal dari bagian utara Rakhine, terletak di bagian barat Myanmar yang dulunya disebut Arakan. Kedatangan dari pedagang muslim dari jazirah Arab pada awal abad ke 7 menandakan permulaan sejarah dari etnis Rohingya di Myanmar. Etnis Rohingya memiliki kemiripan seperti etnis Bengali dari aspek fisik, bahasa dan kebudayaannya (Wekke et.al., 2017). Pemerintah parlementer Myanmar (1948-1956, 1957-1958, 1960-1962) menempatkan Rohingya sebagai etnis dan mereka menikmati hak kewarganegaraan Myanmar. Akan tetapi, sejak tahun 1962, Pemerintah militer menguasai Myanmar yang mengakibatkan etnis Rohingya menerima proses delegitimasi dan persekusi terinstitusionalisasi secara berkelanjutan. Etnis Rohingya tidak termasuk dalam daftar 135 suku asli Myanmar yang dikeluarkan oleh pemerintah. Pada tahun 1982, rezim militer menetapkan 
hukum kewarganegaraan yang bersifat rasisme (anti India dan anti Muslim). Hal ini yang menjadi alat opresif yang legal Pemerintah yang memaksa etnis Rohingya menjadi stateless di tanah kelahirannya sendiri (Islam, 2020).

Gelombang kekerasan yang diterima oleh etnis Rohingya sudah berlangsung beberapa dekade ke belakang, yakni tahun 1942, 1978, 1991-92, 1996, 2012, 2016 dan bulan Agustus 2017. Kekerasan yang terjadi pada tanggal 24 Agustus 2017 dipicu oleh grup pemberontak yang bernama Arakan Rohingya Salvation Army (ARSA) menyerang pos polisi yang mengakibatkan tewasnya 12 tentara Myanmar. Oleh karena itu, Myanmar melancarkan tindakan kekerasan massal terhadap etnis Rohingya yang berada di kawasan Maungdaw, Buthidaung, and Rathedaung. Adapun tindakan kekerasan yang dilakukan antara lain pembakaran rumah dan lahan pertanian, pemukulan, penembakan massal, kekerasan seksual, pembunuhan, serta penguburan massal jenazah etnis Rohingya yang tewas. Mulai tanggal 25 Agustus 2017, gelombang pengungsi ke negara tetangga dimulai dengan tujuan utama ke Cox Bazaar, Bangladesh. Kekerasan yang dilakukan oleh Pemerintah Myanmar mendukung tuduhan adanya pelanggaran HAM berdasarkan Statuta Roma Pengadilan Kriminal Internasional yang masuk dalam definisi kejahatan terhadap kemanusiaan. Namun, hal ini dibantah oleh Pemerintah Myanmar (Haar, et.al, 2019).

Menurut Islam (2019), terjadinya kekerasan terhadap etnis Rohingya di Myanmar dikarenakan absennya norma HAM. Beberapa faktor yang menyebabkan kegagalan norma HAM berlaku di Myanmar antara lain struktur domestik negara Myanmar yang dikuasai militer (tidak demokratis) dan kontrol negara terhadap masyarakat sangat kuat menyebabkan negara tidak dapat menerima norma HAM. Kedua, tidak adanya organisasi massa independen dan institusi hukum domestik. Ketiga, Pemerintah Myanmar sudah mengonstruksi opini publik yang melabel negatif etnis Rohingya. Keempat, tidak adanya kesempatan politik di tengah pemerintahan yang dikuasai oleh junta militer. Kelima, absennya peran institusi internasional dan regional untuk memastikan Myanmar mematuhi norma HAM. Keenam, kepentingan dan kekuatan negara lebih penting dibandingkan norma HAM.

Berdasarkan laporan dari Amnesty International (AI) bahwa sejak tahun 1978, etnis Rohingya telah menerima tindakan represif yang mengakibatkan banyak etnis Rohingya yang pergi meninggalkan kampung halamannya dan mengungsi ke negara tetangga seperti Bangladesh. Kewarganegaraan etnis Rohingya ditolak dan permasalahan HAM tidak mendapatkan perhatian lebih dari Pemerintah Myanmar. Lebih dari 200.000 jiwa mengungsi ke Bangladesh pada tahun 1978. Bahkan jumlah tersebut terus bertambah sampai dengan 250.000 jiwa yang mengungsi ke Myanmar. Kemudian sebanyak 20.000 jiwa pengungsi etnis Rohingya tinggal di pengungsian United Nations High Commissioner for Refugees (UNCHR) yang terletak di Cox's Bazar, Bangladesh (Amnesty Internasional, 2004).

Pengungsi Rohingya juga melarikan diri dari Myanmar ke negara tetangga, termasuk Indonesia. Meskipun tidak berbatasan langsung, tetapi karena pengungsi Rohingya melarikan diri melalui jalur laut yang terkoneksi dengan perairan 
Indonesia di ujung utara Pulau Sumatera. Berdasarkan rilis dari Kemenlu RI pada bulan April 2019, penanganan pengungsi dan pencari suaka dilakukan melalui Desk Penanganan Pengungsi Luar Negeri dan Perdagangan Manusia (P2LNPM) di bawah Kemenko Polhukam. Dalam koordinasinya dengan UNHCR dan IOM, Pemerintah Indonesia memfasilitasi sekitar 13.840 pengungsi dan pencari suaka yang tersebar di berbagai wilayah di Indonesia terlepas dari status Indonesia yang bukan Negara Pihak Konvensi Pengungsi 1951 (Kemlu, 2019).

Gelombang pengungsi yang melarikan diri dari Myanmar ke negara lainnya menimbulkan rasa tidak aman dan instabilitas di kawasan, terutama Asia Selatan dan Asia Tenggara. Keberadaan pengungsi Rohingya menciptakan ancaman keamanan bagi negara yang menerima pengungsi tersebut. Hal ini dikarenakan negara-negara yang menerima pengungsi Rohingya tersebut, tidak dapat menerima secara permanen seluruh pengungsi dan bantuan kemanusiaan hanya bersifat sementara, sehingga kamp pengungsi Rohingya rentan terjadi kekerasan, kejahatan, korupsi dan sebagainya (Rainer \& Goel, 2020).

Sementara dalam kasus Uighur, sejak tahun 1880, tepatnya zaman Dinasti Qing, China telah melakukan aneksasi terhadap wilayah Xinjiang sebagai 'perbatasan baru' bagi China yang memiliki letak strategis. Secara geografis, lokasi yang bernama Xinjiang dikenal dengan nama Turkestan Timur yang merupakan negara dari Turks. China juga menjalankan rencana penempatan atau memperbanyak penduduk dari suku Han (suku mayoritas di China) untuk berdomisili di Xinjiang. Di satu sisi, hal ini menyeimbangkan demografi antara suku Han dan Uighur. Di sisi lain, hal ini menimbulkan perasaan tidak adil dan tidak dihargai dari suku Uighur oleh Pemerintah China. Kombinasi dari situasi politik yang kompleks yang melibatkan negara tetangga yang bersamaan dengan kebangkitan Islam di seluruh dunia. Kemudian transformasi Xinjiang yang menjadi wilayah bagi China dalam pengembangan nuklir dan program luar angkasa. Selain itu, perbatasan Xinjiang dan Rusia serta potensi pengembangan kilang minyak dan gas menjadikan wilayah ini menjadi wilayah yang penting bagi China (Israeli, 2010).

Permasalahan etnis Uighur di China berkaitan erat dengan gerakan terorisme, separatisme dan radikalisme. Hal ini membuat China menerapkan kebijakan-kebijakan otoritarian di Xinjiang. Kebijakan-kebijakan yang diambil oleh Pemerintah China memberikan ancaman bagi keamanan sosial bagi etnis Uighur, karena identitas etnis Uighur terancam oleh tindakan yang diambil oleh pemerintah China (Clarke, 2008). Pemerintah China memiliki dua pendekatan terhadap Uighur di Xinjiang, yakni pendekatan lunak dan keras. Pendekatan lunak memiliki karakteristik toleransi relatif dan mendorong institusionalisasi Islam melalui pembangunan masjid yang dibiayai Pemerintah dan asosiasi Muslim China di bawah pengawasan pemerintah. Sedangkan pendekatan keras memiliki karakteristik kampanye melawan institusi yang tidak diakui pemerintah, pembangunan masjid-masjid 'ilegal', re-edukasi dan reformasi pemimpin agama. Hal ini menimbulkan kekecewaan dari etnis Uighur yang menganggap pendekatan keras tersebut merupakan bagian dari upaya China melemahkan identitas Uighur. (Clarke, 2010). 
Kebijakan China di Xinjiang juga dipengaruhi oleh peristiwa 9/11 di AS. China merespon isu terorisme pasca 9/11, yakni China merekonfigurasi diskursus etnis Uighur di Xinjiang dengan merefleksikannya terhadap fokus internasional terhadap terorisme berdasarkan agama dan ekstrimisme (Clarke, 2010). Pada Desember 2002, Pemerintah AS menempatkan East Turkestan Islamic Movement sebagai organisasi teroris internasional. Hal ini secara tidak langsung menjustifikasi kebijakan China dalam melakukan perang melawan terorisme, yang sejalan dengan kebijakan internasional AS memerangi terorisme pasca peristiwa 9/11 (Clarke, 2008). Hal ini melegitimasi tindakan China dalam melawan terorisme Uighur (Clarke, 2010). Kebijakan-kebijakan China di Xinjiang ditempuh untuk mempertahankan Xinjiang tidak merdeka dan terpisah dari China, meskipun cara-cara yang digunakan tergolong keras dan melanggar HAM.

Seiring dengan perkembangannya, permasalahan di Xinjiang juga terus berkembang dan terus meningkat ekskalasinya. Pada tahun 2014, pemerintah China memulai program "Strike Hard Campaign against Violent Extremism", yang terus meningkat tingkat represinya ketika Chen Quanguo menjadi Sekretaris Partai Komunis China di Xinjiang pada tahun 2016. Estimasi sebanyak 1 juta penduduk Xinjiang ditahan di kamp-kamp untuk mempelajari bahasa mandarin, menyanyi lagu-lagu Partai Komunis China dan menghafal peraturan-peraturan yang berlaku terhadap muslim Xinjiang. Adapun masyarakat yang tidak patuh dan gagal diedukasi akan menerima hukuman (Human Rights Watch, 2018a). Berdasarkan data dari China Human Rights Watch Defenders, sebanyak 11 juta etnis Uighur ditahan di Xinjiang pada tahun 2017 (Cumming-Bruce, 2018).

Pada 2018, Human Rights Watch menemukan kebijakan China yang melakukan penahanan massal, penyiksaan, pemaksaan indoktrinasi politik dan pengawasan massal terhadap muslim Xinjiang. Selain itu, pejabat pemerintah Xinjiang juga melakukan pengumpulan DNA dan sampel suara sebagai upaya melacak keberadaan penduduk Xinjiang. Akan tetapi, China tidak bergeming terhadap tuduhan tersebut (Wang, 2020). Para pejabat pemerintah China juga membantah adanya penyiksaan; sebaliknya mereka mencirikan kamp-kamp tersebut sebagai "pendidikan kejuruan dan pusat pelatihan kerja" untuk "para pelaku kejahatan ringan." Namun, pemerintah China tidak memberikan izin masuk ke kamp tersebut bagi kelompok independen dari PBB, organisasi pembela HAM dan media massa (Human Rights Watch, 2018b).

\section{Identitas dan Kepentingan Indonesia dalam Isu Rohingya}

Indonesia yang terletak di wilayah Asia Tenggara merupakan salah satu negara pendiri ASEAN yang terbentuk pada 8 Agustus 1967 di Bangkok, Thailand. Hal ini ditandai oleh penandatanganan Deklarasi ASEAN oleh lima pendiri dari Indonesia, Malaysia, Filipina, Singapura dan Thailand. Seiring dengan berjalannya waktu, keanggotaan ASEAN terus berkembang yang ditandai dengan bergabungnya Brunei Darussalam pada 7 Januari 1984. Kemudian, Vietnam pada 28 Juli 1995, Laos dan Myanmar pada 23 Juli 1997 serta Kamboja pada 30 April 1999 (ASEAN, 2019). 
Di samping sebagai salah satu pendiri ASEAN, Indonesia banyak berkontribusi dalam kerja sama dalam lingkup ASEAN. Hal ini melahirkan penghargaan dan pengakuan dari anggota ASEAN lainnya sebagai 'primus inter pares' atau pertama di antara sesama anggota ASEAN. Sebagai negara terbesar di ASEAN, dukungan Indonesia terhadap ASEAN merupakan hal yang penting dalam keberlanjutan dan kesuksesan ASEAN (Anwar, 1997). Persepsi terhadap Indonesia sebagai "pemimpin alami dari ASEAN" secara otomatis memberikan pengaruh kepada pimpinan negara Indonesia dalam bersikap dalam kerangka baik secara bilateral maupun multilateral (Hadi, 2012). Maka, tidak mengherankan jika Indonesia selalu menjadi negara pertama yang memulai penyelesaian konflik atau permasalahan yang terjadi di kawasan ASEAN. Hal ini dapat dilihat dari beberapa permasalahan penting yang menjadi perhatian Indonesia antara lain ketegangan di perbatasan Kamboja dan Thailand, sengketa teritorial di Laut Cina Selatan dan represi Rohingya di Myanmar (Roberts et.al., 2015). Dengan demikian, kontruksi identitas Indonesia tidak dapat dilepaskan dari ASEAN. Mengingat Indonesia merupakan salah satu inisiator berdirinya ASEAN, sedangkan Myanmar merupakan anggota baru dalam organisasi ASEAN.

Permulaan awal interaksi Indonesia dengan isu Rohingya ketika etnis Rohingya mulai mengungsi ke negara lain, termasuk Indonesia. Pada awalnya Indonesia tidak ingin menerima pengungsi Rohingya untuk masuk ke wilayah Indonesia. Namun, pemerintah melalui TNI AL ditugaskan untuk tetap menjaga teritorialnya, namun tetap membantu pengungsi Rohingya yang bertahan diri di kapal seperti membawakan makanan dan air bersih. Sikap Indonesia tersebut mendapat peringatan dari PBB. Peringatan tersebut juga diterima oleh Malaysia dan Thailand yang menolak pengungsi Rohingya. Maka, Indonesia mulai lebih aktif untuk menangani dan menerima pengungsi Rohingya. Presiden RI, Joko Widodo mengutus Menlu Retno Marsudi untuk mendiskusikan permasalahan pengungsi di tingkat regional melalui ASEAN. Pengungsi Rohingya patut diterima oleh seluruh negara di ASEAN, bukan hanya Indonesia saja. Hal ini berdampak pada Thailand dan Malaysia yang membuka pintu untuk pengungsi Rohingya (Sari, 2018). Teguran PBB terhadap Indonesia menjadi dorongan untuk tetap menjadi inisiator permasalahan ini ke ranah regional untuk diselesaikan bersama-sama demi rasa kemanusiaan dan perdamaian di kawasan yang merupakan amanat dari Piagam ASEAN (ASEAN Charter, 2017).

Dalam kesempatan Konferensi Tingkat Tinggi (KTT) ASEAN ke-35 di Thailand pada bulan November 2019 lalu, telah disepakati bahwa ASEAN akan membentuk Satuan Tugas Ad Hoc untuk membantu proses repatriasi pengungsi Rohingya dari Bangladesh ke Myanmar. Satgas ini akan bekerja di bawah Sekretariat ASEAN untuk mengawasi pelaksanaan rekomendasi penilaian kebutuhan awal (Preliminary Needs Assessment) yang berdasarkan laporan ASEAN Coordinating Centre For Humanitarian Assistance bersama dengan ASEAN Emergency Response and Assessment Team (Pramudyani, 2019). Dalam kesempatan tersebut, Presiden Joko Widodo juga menegaskan bahwa Indonesia menaruh perhatian besar bagi upaya pemulihan situasi dan keamanan di Rakhine State, Myanmar, serta menekankan pentingnya repatriasi pengungsi Rohingya (Dikarma \& Candra, 2019).

Identitas Indonesia sebagai pemimpin di ASEAN, membuat Indonesia bergerak di ranah kesepakatan-kesepakatan yang telah ditetapkan dan disetujui untuk dilaksanakan secara bersama-sama oleh semua anggota ASEAN. Mengacu 
kepada Treaty of Amity and Cooperation (TAC) ASEAN yang telah ditetapkan pada 24 February 1976, bahwa tujuan dari TAC adalah untuk menjaga perdamaian abadi, persahabatan dan kerja sama di antara masyarakat yang ikut berkontribusi dengan memberikan kekuatan, solidaritas dan hubungan yang erat (ASEAN, 2016). Berdasarkan kesepakatan tersebut, maka Indonesia dan Myanmar ikut berkepentingan menjaga perdamaian di kawasan Asia Tenggara.

Dalam menjaga perdamaian di kawasan, maka diperlukan cara yang tepat di tengah keberagaman budaya dan norma yang ada di masing-masing negara. Hal ini yang membentuk 'cara ASEAN' (ASEAN Way) dalam menangani masalahmasalah yang muncul di kawasan. Fokus dari ASEAN Way terdapat pada tindakan preventif dan manajemen konflik intra-regional, meskipun hal ini tentunya akan bersinggungan dengan pemberontakan dalam negeri dan intervensi dari luar. Akan tetapi, hal ini dilakukan untuk meminimalisir potensi memburuknya ketegangan antar negara di ASEAN. Selain mencegah peningkatan ekskalasi menuju konflik bersenjata, ASEAN Way juga bertujuan untuk mencegah dampak buruk dari permasalahan domestik dan menunjukkan kepada negara lain di luar kawasan bahwa ASEAN tetap menolak adanya intervensi dari kekuatan besar dalam masalah yang terjadi di ASEAN (Acharya, 1998).

Dengan tetap menjaga prinsip ASEAN Way, Indonesia berupaya menyelesaikan krisis kemanusiaan di Myanmar. Hal ini dapat dilihat dari kesuksesan Indonesia membawa isu etnis Rohingya dua kali dalam Rapat Pleno ASEAN Intergovernmental Commission on Human Rights (AIHCR) pada 2018. Indonesia juga berhasil membawa pembicaraan terkait etnis Rohingya secara informal yang dihadiri oleh perwakilan masing-masing negara anggota ASEAN. Melalui pertemuan tersebut, Indonesia berhasil menjadwalkan diskusi secara berkala satu tahun sekali terkait etnis Rohingya. Di sisi lain, Indonesia memiliki kepentingan sebagai sebuah negara sahabat dari Myanmar yang memiliki sejarah panjang sejak era Presiden Soekarno. Oleh karena itu, Indonesia dapat memberikan solusi terhadap permasalahan etnis Rohingya tanpa mengecilkan Myanmar sebagai sebuah negara berdaulat. Prinsip utama yang dilakukan oleh Indonesia adalah mengedepankan peran Myanmar untuk menyelesaikan permasalahan domestiknya sendiri yang diikuti dengan memberikan solusi mulai dari jangka pendek hingga jangka panjang (Purnama, et.al, 2019).

\section{Identitas dan Kepentingan Indonesia dalam Isu Uighur}

Konstruksi identitas Indonesia terhadap China berbeda dengan konstruksi identitas terhadap Myanmar. Ketika Indonesia menghadapi Myanmar, maka kontruksi identitas yang melekat adalah negara anggota ASEAN. Sedangkan China bukan sebagai negara anggota ASEAN, sehingga identitas tetap berlaku tetapi tidak bersifat dominan. Berdasarkan sejarahnya, hubungan China dan negara Asia Tenggara sudah berlangsung sejak zaman dahulu. Hubungan tersebut terjewantahkan sistem upeti. Kerajaan-kerajaan di kawasan Asia Tenggara memberikan upeti kepada Dinasti di China untuk mendapatkan jaminan status dan perlindungan. Dalam konteks hubungan China dan Indonesia, maka didominasi hubungan perdagangan terutama pelabuhan-pelabuhan di pesisir Pulau Jawa dan Sumatera (Stuart-Fox, 2004). 
China sebagai negara rising power berusaha kembali meningkatkan perannya di tingkat internasional baik regional maupun global, termasuk di kawasan Asia Tenggara. Hal ini didukung dengan pemikiran China yang disebut dengan wilayah perbatasan strategis yang terdiri dari Asia Timur Laut, Asia Selatan, Asia Tenggara dan Asia Tengah. Dengan demikian, China dikenal negara berkembang dan major power yang berusaha memperluas kepemimpinannya di antara negara-negara berkembang (Eisenman \& Heginbotham, 2019). Oleh karena itu, identitas Indonesia terhadap China sebagai negara berkembang dan berkekuatan menengah (middle power) atau tidak sehebat kekuatan China.

Gagasan negara negara berkekuatan menengah semakin sering digunakan dalam rangka menjelaskan perilaku sebuah negara (Karim, 2018). Di dalam sistem internasional yang dihegemoni oleh kekuatan besar, negara middle power sebetulnya tidak memiliki kapasitas yang cukup besar untuk mengatur arah sistem internasional. Negara-negara besar menjadi aktor yang lebih menentukan bagaimana sistem internasional bekerja. Di sisi lain, negara middle power juga memiliki kapasitas yang terbatas untuk menyesuaikan diri dengan perubahanperubahan yang terjadi di dalam sistem internasional (Alvian, Putri \& Ardhani, 2018).

Indonesia memperkenalkan identitasnya sebagai negara berkekuatan menengah pada zaman Susilo Bambang Yudhoyono (SBY). Pada 2012, SBY menyampaikan konsep negara kekuatan menengah yang berperan sebagai pembuat jembatan antara negara maju dengan negara berkembang. Namun demikian, Indonesia secara jelas menggambarkan posisinya yang dapat dikatakan menjauh dari Amerika Serikat. Di sisi lain, Indonesia juga ikut dalam ambisi negara BRICS yang revisionis. Akan tetapi, Indonesia akan memainkan peran sebagai revisionis lunak dan pada waktu yang bersamaan memainkan peran sebagai negara penyambung yang normatif (Sriyanto, 2018: 12).

Setelah Joko Widodo terpilih menjadi presiden ke tujuh, ia memasukkan gagasan negera berkekuatan menengah dalam program kampanye Pilpres tahun 2014 lalu. Indonesia berperan sebagai negara kekuatan menengah melakukan pemilihan kerjasama secara selektif terhadap isu regional dan global. Di sisi lain, Indonesia juga diharapkan dapat memperluas lingkup kebijakan luar negeri Indonesia dalam rangka menghadapi tantangan dari Indo-Pasifik. Pemerintah Joko Widodo-Jusuf Kalla menekankan sentralitas ASEAN dengan memadukan strategi melalui forum bilateral dan multilateral (Sriyanto, 2018: 13). Meskipun Indonesia membawa identitas sebagai negara kekuatan menengah, kebijakan luar negeri Indonesia di bawah Jokowi berbeda dengan di masa SBY. Ketika Jokowi dilantik sebagai presiden, maka dengan tegas ia menyatakan era "a thousand friends, zero enemies" yang dipromosikan oleh SBY sudah berakhir. Joko Widodo lebih mengedepankan pendekatan transaksional dengan negara lain yang lebih menguntungkan Indonesia (Lundry, 2018). Presiden Joko Widodo berkomitmen untuk menjaga "kebebasan dalam menentukan arah hubungan luar negeri yang mengabdi pada kepentingan nasional" serta "menempatkan Indonesia sebagai kekuatan regional dengan keterlibatan global secara selektif, dengan memberi prioritas pada permasalahan yang secara langsung berkaitan dengan kepentingan bangsa dan rakyat Indonesia" (Alvian, Putri \& Ardhani, 2018). 
Slogan "a thousand friends, zero enemies" dianggap berjarak antara kebijakan luar negeri dengan kebutuhan dalam negeri. Kebijakan luar negeri ditempatkan di tingkatan yang tinggi, tetapi lemah dalam menyelesaikan permasalahan dalam negeri Indonesia (Andika, 2016). Visi politik luar negeri Presiden Joko Widodo beresonansi dengan kritik terhadap politik luar negeri SBY yang dirasa elitis dan tidak punya hubungan langsung dengan kepentingan nasional Indonesia, khususnya pengembangan ekonomi dalam negeri (Alvian, Putri \& Ardhani, 2018).

SBY membawa Indonesia sebagai negara kekuatan menengah yang aktif dalam forum internasional di tingkat regional dan global. Namun hal tersebut berubah ketika memasuki era Presiden Joko Widodo, Indonesia sebagai negara berkekuatan menengah yang lebih memandang ke dalam (inward looking). Pertimbangan perubahan ini dikarenakan permasalahan domestik yang masih banyak belum terselesaikan. Indonesia memiliki kepentingannya sendiri dan aspirasi masyarakat Indonesia juga patut diperhatikan. Indonesia bergeser menjadi lebih tegas yang dapat diinterpretasikan negara yang nasionalistik dan mementingkan kepentingan nasionalnya sendiri (Madu, 2015).

Arah pembangunan Indonesia yang berdasarkan program Nawacita dan Poros Maritim Dunia lebih menekankan kepada pembangunan infrastruktur dan konektivitas antar wilayah di Indonesia, sehingga pemerataan pembangunan di Indonesia dapat terwujud. Dengan demikian, Indonesia membutuhkan dana untuk mencapai kepentingan nasionalnya salah satunya dengan menerima investasi dari luar negeri. China sebagai negara mitra dagang dan negara penarik upeti kerajaan-kerajaan nusantara zaman dahulu, maka tidak asing bagi Indonesia menjalin kembali hubungan dengan China. Meskipun sebelumnya hubungan Indonesia dan China sempat membeku pasca tahun 1965 (Sukma, 2009).

Kepentingan Indonesia secara umum dapat tergambar dari kebijakan luar negeri dari Presiden Joko Widodo yang memiliki empat karakteristik, yakni mengedepankan ideologi nasionalisme. Kedua, terdapat tendensi mempersempit kepentingan strategis Indonesia. Ketiga, kekuatan nasional harus berdasarkan kapabilitas domestik, yang terwujud dalam diplomasi ekonomi. Keempat, mempersempit konsep kepentingan nasional dalam wujud material, yakni kekuatan, kekayaan dan keamanan (Rosyidin, 2017). Berdasarkan karakteristik tersebut, maka kepentingan Indonesia terhadap China cenderung bersifat material demi mewujudkan kepentingan nasionalnya.

Presiden Joko Widodo menekankan pembangunan infrastruktur menjadi prioritas utama dalam kampanye dan terus diwujudkan ketika menjabat presiden. Hal ini dikarenakan infrastruktur di Indonesia tertinggal dan menjadi permasalahan di Indonesia seperti mengurangi daya saing ekonomi Indonesia, memperlebar kesenjangan ekonomi antara bagian barat dan bagian timur Indonesia, dan masalah lainnya. China menjadi mitra favorit sumber pendanaan dalam pemerintahan Joko Widodo untuk mengejar pembangunan infrastruktur di Indonesia, salah satunya dengan bergabungnya Indonesia dengan Asian Investment Infrastructure Bank (AIIB) (Anwar, 2019). 
Statistik United Nations Conference on Trade and Development (UNCTAD) menyatakan lima negara mitra ekspor Indonesia pada tahun 2018, yakni China dengan nilai sebesar US $\$ 27,127$ juta, Jepang dengan nilai sebesar US $\$ 19,480$ juta, Amerika Serikat US\$ 18,472 juta, India dengan nilai sebesar US\$ 13,726 juta dan Singapura dengan nilai sebesar US\$ 12,992 juta (UNTAD, 2019). Berdasarkan data Badan Koordinator Penanaman Modal (BKPM), pertumbuhan investasi di periode semester I tahun 2019 mencapai Rp. 395,6 triliun yang berkontribusi 49,9\% dari target 2019. Dari sisi Penanaman Modal Asing (PMA) Rp. 212,8 triliun atau naik $4 \%$ year on year (yoy). Sementara Penanaman Modal Dalam Negeri (PMDN) sebesar Rp. 182,8 triliun, angka ini lebih tinggi 16,4\% dari periode yang sama tahun lalu. Kemudian lima negara dengan investasi terbesar di Indonesia antara lain Singapura sebesar 24,5\% atau US\$ 1,7 miliar, Jepang sebesar 17,5\% setara US\$ 1,2 miliar, China 16,2\% sebesar US\$ 1,1 miliar, Hongkong 10,4\% sebesar US\$ 0,7 miliar dan Belanda 5,3\% atau sebesar US\$ 0,4 miliar (Santoso, 2019).

Naiknya peringkat China menjadi negara investor ketiga terbesar bagi Indonesia tidak terlepas dari kebijakan Belt Road Initiative (BRI) China dengan nilai investasi sebesar US\$2,3 Miliar yang mencakup 1.562 proyek. Hal ini mendatangkan sekitar 1.000 perusahaan China dan sebanyak 25.000 Tenaga Kerja Asing (TKA) asal China ke Indonesia. Proyek-proyek pembangunan yang bekerja sama dengan China seperti Kereta Cepat Jakarta-Bandung, pembangunan bandara di Sulawesi dan sebagainya (Rakhmat \& Nugroho, 2019). Hal ini tidak terlepas dari karakteristik investasi langsung China di Indonesia, yaitu dalam kurun waktu 2006-2016 investasi China di Indonesia dalam nominal mengalami fluktuasi, akan tetapi proyek investasi di Indonesia terus meningkat. Investasi langsung China juga terbagi menjadi dua bagian, yakni fase pertumbuhan stabil dalam periode 2006-2012 dan fase pertumbuhan cepat pada tahun 2013-2016. Karakteristik kedua berdasarkan geografis, investasi China secara umum lebih tinggi di bagian barat Indonesia dibandingkan bagian timur Indonesia, serta bagian selatan lebih tinggi dibandingkan bagian utara (Fu, et.al, 2018). Dengan melihat data tersebut, maka Indonesia menempatkan China sebagai negara mitra yang penting dalam hubungan luar negeri dan kerja sama ekonomi. Maka, keterkaitan Indonesia dengan China cukup kuat yang membuat hubungan kedua negara menjadi lebih dekat (Umagapi, 2017).

\section{Perbedaan Sikap Indonesia terhadap Isu Rohingya dan Uighur}

Identitas Indonesia sebagai leading actor di ASEAN dan kepentingan Indonesia untuk tetap menjaga perdamaian dan keamanan di kawasan Asia Tenggara saling memengaruhi satu dengan lainnya. Hal ini menghasilkan sikap Indonesia yang lebih aktif dalam penyelesaian konflik dan penanganan permasalahan etnis Rohingya di Myanmar. Dalam tataran bilateral, Indonesia melakukan kunjungan diplomatik dengan bertemu dengan Aung San Suu Kyi dan Jenderal Min Aung Hlaing dalam rangka mendiskusikan resolusi konflik dan perizinan terkait pemberian bantuan kemanusiaan termasuk pembangunan rumah 
sakit di Mrauk U, Rakhine State. Kemudian Indonesia membawa permasalahan ini ke tingkat regional, pada 20 Mei 2015, ASEAN menyelenggarakan pertemuan darurat di Putra Jaya, Malaysia untuk mendiskusikan permasalahan pengungsi Rohingya yang dihadiri oleh Malaysia, Thailand dan Indonesia (minus Myanmar). Pertemuan tersebut menghasilkan kesepakatan, yakni Indonesia akan mengakomodasi sebanyak 7.000 pengungsi Rohingya dalam kurun waktu satu tahun. Hal ini bertujuan untuk memberikan waktu kepada UNHCR dalam melakukan pengumpulan data dan menunggu UNHCR menemukan negara ketiga sebagai tujuan dari para pengungsi atau kembali ke Myanmar (Sari, 2018: $10)$.

Meskipun belum ada mekanisme regional di ASEAN yang mengatur terkait perlindungan pengungsi, Indonesia, Thailand dan Malaysia mengambil inisiatif dan upaya dalam merespon permasalahan krisis Rohingya pada tahun 2015, melalui hukum dan kebijakan dari masing-masing negaranya. Ketiga negara tersebut menyepakati perlindungan sementara terhadap pengungsi Rohingya yang terdampar di wilayahnya dalam jangka waktu satu tahun (Dewansyah \& Handayani, 2018). Selain itu, Indonesia juga mengambil sikap di tingkat global dengan ikut berpartisipasi dalam dalam pembahasan penyusunan Global Compact for Orderly Migration and Refugees sejak tahun 2015 hingga diadopsinya Deklarasi New York untuk Pengungsi dan Migran oleh Majelis Umum PBB di tahun 2016. Adapun mandat dari Deklarasi New York adalah penyusunan Global Compact on Refugees (GCR) yang bertujuan untuk mengurangi beban negara penerima pengungsi. Kedua, meningkatkan kemandirian pengungsi. Ketiga, memperluas solusi yang berfokus kepada peran negara ketiga (expanding third-country solutions). Keempat, mendukung kondisi yang kondusif bagi pemulangan sukarela dan berkelanjutan bagi para pengungsi (Kemlu, 2019).

Namun demikian, sikap Indonesia dipengaruhi oleh pandangan kebijakan luar negeri yang ditentukan oleh pimpinan negara, dalam hal ini Presiden Joko Widodo. Ketika Presiden Joko Widodo terpilih pada tahun 2014, maka kebijakan luar negeri Indonesia ikut berubah. Sebelumnya, Indonesia di bawah Presiden Susilo Bambang Yudhoyono menempatkan Indonesia sebagai pemimpin di tingkat regional, yakni pemimpin ASEAN (Karim, 2016). Akan tetapi, Indonesia di bawah Presiden Joko Widodo menempatkan kepentingan domestik sebagai prioritas utama dibandingkan kepentingan status Indonesia di tingkat internasional (Rosyidin, 2017). Hal ini dapat terlihat dari sikap Indonesia yang dapat dikatakan lambat dan sempat menolak pengungsi Rohingya pada awalnya, namun mengubah sikap karena adanya teguran PBB, serta etnis Rohingya sudah memasuki wilayah kedaulatan Indonesia.

Berbeda dengan sikap Indonesia yang ditunjukkan dalam merespon permasalahan etnis Rohingya, sikap Indonesia terhadap permasalahan Uighur di China tidak seaktif ketika mengatasi permasalahan etnis Rohingya. Di sisi lain, permasalahan etnis Uighur bukan menjadi hal yang urgen untuk diselesaikan. Di sisi lain, kepentingan Indonesia lebih condong terhadap hubungan ekonomi dan perdanganan dengan China, terutama dalam menjaga arus investasi dari China untuk tetap masuk ke Indonesia. 
Identitas Indonesia sebagai negara yang kekuatan menengah yang berpandangan ke dalam (nasionalis), membuat Indonesia lebih aktif dalam forum bilateral yang menguntungkan bagi Indonesia terutama dalam bidang perekonomian. Hubungan Indonesia dengan China dapat dikatakan baik, meskipun terdapat hambatan dan kendala dalam perjalanannya. Investasi China yang mencapai US\$ 1,1 miliar membuat China menjadi mitra penting bagi Indonesia. Di sisi lain, terdapat kecenderungan dari negara muslim dunia, termasuk Indonesia, dalam membina hubungan dengan China demi mendapatkan dukungan politik di tingkat internasional yang bertujuan untuk menyeimbangkan kekuatan negara barat di kawasan (Kelemen \& Turcsányi, 2020).

IndonesiamelihatpermasalahanetnisUighurdiChinasebagaipermasalahan separatis di dalam negeri China. Jika Indonesia merespon permasalahan tersebut, maka Indonesia juga perlu menerima saran dan masukan dari China terkait permasalahan Papua. Indonesia juga memandang laporan terkait pelanggaran HAM di Xinjiang secara skeptis, cenderung melihat laporan tersebut sebagai bagian dari propaganda Amerika Serikat di tengah persaingan kekuatan dengan China (IPAC, 2019: 1). Sikap Indonesia dipertegas oleh pernyataan Munajat (Staf Ahli Deputi-V Kantor Staf Presiden/KSP) yang menyatakan bahwa permasalahan Uighur merupakan permasalahan politik domestik China dan tidak ingin terlibat lebih jauh dalam permasalahan etnis Uighur, karena hal tersebut akan memperkuat kelompok Islam radikal di Indonesia. Permasalahan diplomatik Indonesia dengan China lainnya, seperti pengaruh China di Laut China Selatan dan destabilisasi keamanan regional di Asia Tenggara, yang perlu mendapatkan perhatian lebih dari Indonesia (IPAC, 2019: 13).

Desakan elemen masyarakat Indonesia untuk bersikap tegas terhadap permasalahan etnis Uighur di China tidak menjadi prioritas utama bagi Indonesia. Selain itu, hal ini ditempuh sebagai langkah menjaga hubungan baik dengan China. Adapun sikap Indonesia dalam politik luar negeri sudah digariskan dalam Nawacita dan Rencana Pembangunan Jangka Menengah Nasional (RPJMN), yakni keamanan dan perdamaian. Kedua, diplomasi ekonomi. Ketiga, perlindungan Warga Negara Indonesia (WNI) dan Badan Hukum Indonesia (BHI) di luar negeri. Keempat, kerja sama ASEAN. Terakhir, diplomasi maritim (Fitriani \& Panduwinata, 2018). Adapun Indonesia secara formal telah memanggil Duta Besar China untuk Indonesia sebagai bentuk diplomasi antar kedua negara dengan membicarakan permasalahan etnis Uighur di China. Indonesia juga lebih menghormati China dalam mengurus permasalahan dalam negerinya tanpa melakukan intervensi lebih jauh. Hal ini juga terlihat dengan abstainnya Indonesia dalam bersikap terhadap permasalahan etnis Uighur di tingkat internasional. 


\section{Kesimpulan}

Indonesia dalam berinteraksi dengan aktor lain di dunia internasional membawa identitas yang berbeda. Hal ini dapat terlihat dari sikap Indonesia dalam merespon dua permasalahan yang berbeda, yaitu permasalahan etnis Rohingya di Myanmar dan etnis Uighur di China. Perbedaan sikap Indonesia dipengaruhi oleh identitas dan kepentingan yang Indonesia miliki dalam berinteraksi dalam rangka merespon permasalahan tersebut. Identitas dan kepentingan Indonesia yang berbeda dan saling memengaruhi membentuk sikap Indonesia yang berbeda dalam merespon permasalahan tersebut.

Di sisi lain, kedua permasalahan etnis Rohingya dan Uighur bersentuhan dengan Islam. Akan tetapi, Indonesia tidak memunculkan identitas Islam dalam merespon permasalahan tersebut. Hal ini dimungkinkan karena perbedaan persepsi Indonesia terhadap permasalahan tersebut terutama terhadap aktor nonnegara, yakni etnis Rohingya dan Uighur. Di satu sisi, Indonesia yang berinteraksi dengan etnis Rohingya sebagai pengungsi membentuk persepsi kemanusiaan yang menjadikan etnis Rohingya sebagai entitas yang perlu diselamatkan agar tetap dapat bertahan hidup. Namun demikian, interaksi Indonesia dengan etnis Uighur dapat dikatakan jarang dan tidak langsung. Adapun Indonesia lebih condong terhadap persepsi ancaman daripada persepsi kemanusiaan terhadap etnis Uighur di China yang juga lekat dengan tindak terorisme dan separatisme.

Dengan dunia yang terus berubah begitu cepat, maka konstruksi sosial yang dibentuk dari interaksi sosial antar aktor di dunia internasional juga akan terus ikut berubah. Hal ini juga mengakibatkan identitas dan kepentingan Indonesia dapat terus berubah dan terekonstruksi kembali di masa mendatang yang mengikuti dinamika dunia internasional yang melahirkan perilaku atau sikap Indonesia yang juga dapat berbeda-beda.

\section{Daftar Pustaka}

Acharya, A. (1998). Culture, Security, Multilateralism: The "ASEAN Way" and Regional Order. Contemporary Security Policy, 19(1), pp. 55-84.

Alvian, R. A., Putri, G. C., \& Ardhani, I. (2018). Haluan Baru Politik Luar Negeri Indonesia: Perbandingan Diplomasi 'Middle Power' Susilo Bambang Yudhoyono dan Joko Widodo. Jurnal Hubungan Internasional, 6(2), pp. 148163.

Amnesty International. (2004). The Rohingya Minority:Fundamental Rights Denied. Tersedia dalam: <https://www.amnesty.org/download/Documents/92000/ asa160052004en.pdf $>$ [diakses 27 November 2019].

Andika, M. T. (2016). An Analysis of Indonesia Foreign Policy Under Joko Widodo's Pro-People Diplomacy. Indonesian Perspective, 1(2), pp. 93-105.

Anwar, D. F. (1997). ASEAN and Indonesia: Some Reflections. Asian Journal of Political Science, 5(1), pp. 20-34.

Anwar, D.F. (2019). Indonesia-China Relations: To Be Handled With Care. ISEAS Perspective. No. 19.

ASEAN. (2019). About ASEAN [Online]. Tersedia dalam: <https://asean.org/asean/ about-asean/> [diakses pada 27 November 2019]. 
ASEAN. (2016). Treaty of Amity and Cooperation in Southeast Asia Indonesia, 24 February 1976 [Online]. Tersedia dalam: <https://asean.org/treatyamity-cooperation-southeast-asia-indonesia-24-february-1976/> [diakses 27 November 2019].

ASEAN. (2017). ASEAN Charter. Jakarta: ASEAN Secretariat.

Cumming-Bruce, N. (2018). U.N. Panel Confronts China Over Reports that It Holds a Million Uighurs in Camps [Online]. Tersedia dalam: <https:// www.nytimes.com/2018/08/10/world/asia/china-xinjiang-un-uighurs.html> [diakses pada 24 November 2019].

Dewansyah, B \& Handayani, I. (2018). Reconciling Refugee Protection and Sovereignity in ASEAN Member States: Law and Policy Related to Refugee in Indonesia, Malaysia, dan Thailand. The Central European Journal of International and Security Studies (CEJISS), 12(4), pp. 473-485.

Dikarma, K\& Candra, S.A. (2019). KTT ASEAN Soroti Isu Kemanusiaan di Rohingya [Online]. Tersedia dalam: <https://www.republika.co.id/berita/nasional/ news-analysis/19/11/04/q0few1282-ktt-asean-soroti-isu-kemanusiaan-dirohingya> [diakses pada 29 April 2020].

Fitriani \& Panduwinata, V.C. (2018). Analisis Kinerja Kementerian Luar Negeri Indonesia (2015-2018). Jakarta: CSIS.

$\mathrm{Fu}, \mathrm{Y}$, et.al. (2018). China's Outward FDI in Indonesia: Spatial Patterns and Determinants. Sustainability, 10(12), pp. 1-20.

Hadi, S. (2012). Indonesia, ASEAN, and the Rise of China: Indonesia in the Midst of East Asia's Dynamics in the Post-Global Crisis World. International Journal of China Studies, 3(2), pp. 151-166.

Haar, R.J., et.al. (2019). Documentation of human rights abuses among Rohingya refugees from Myanmar. Conflict and Health, 13(1), pp. 1-14.

Human Rights Watch. (2018a). China: Massive Crackdown in Muslim Region, Mass Arbitrary Detention, Religious Repression, Surveillance in Xinjiang [Online]. Tersedia dalam: <https://www.hrw.org/news/2018/09/09/chinamassive-crackdown-muslim-region> [diakses pada 17 Oktober 2020].

Human Rights Watch. (2018b). Eradicating Ideological Viruses, China's Campaign of Repression Against Xinjiang's Muslims [Online]. Tersedia dalam: <https:// www.hrw.org/report/2018/09/09/eradicating-ideological-viruses/chinascampaign-repression-against-xinjiangs> [diakses pada 17 Oktober 2020].

Human Rights Watch. (2019). Rohingya Crisis [Online]. Tersedia dalam: <https:// www.hrw.org/tag/rohingya-crisis> [diakses 24 November 2019].

Islam, M. S. (2019). Understanding the Rohingya Crisis and the Failure of Human Rights Norm in Myanmar: Possible Policy Responses. Jadavpur Journal of International Relations, 23(2), pp. 158-178.

Islam, N. (2020). Rohingya: A People under Endless Tyranny. Asian Affairs: An American Review. DOI: 10.1080/00927678.2020.1793631.

Israeli, R. (2010). China's Uyghur Problem. Israel Journal of Foreign Affairs, 4(1), pp: 89-101.

Karim, M. F. (2017). Role Conflict and the Limits of State Identity: the Case of Indonesia in Democracy Promotion. The Pacific Review, 30(3), pp. 385-404.

Karim, M. F. (2018). Middle Power, Status-Seeking and Role Conceptions: The Cases of Indonesia and South Korea. Australian Journal of International Affairs, 72(4), pp. 343-363. 
Kelemen, B. \& Turcsányi, R. Q. (2020). It's the Politics, Stupid: China's Relations with Muslim Countries on the Background of Xinjiang Crackdown. Asian Ethnicity, 21(2), pp. 223-243.

Kemlu. (2019) Isu-Isu Kemanusiaan [Online]. Tersedia dalam: <https://kemlu. go.id/portal/id/read/88/halaman_list_lainnya/isu-isu-kemanusiaan> [diakses pada 27 November 2019].

Kumparan. (2019). 7 Sikap Indonesia terkait Krisis Rohingya [Online]. Tersedia dalam: <https://kumparan.com/kumparannews/7-sikap-indonesia-terkaitkrisis-rohingya> [diakses 24 November 2019].

Kusuma, A.J, et.al. (2019). Analisis Perkembangan Norma Internasional 'War on Terror' dalam Perspektif Realis, Liberalis dan Konstruktivis. Indonesian Perspective, 4(1), pp. 1-19.

Lundry, C. (2018). Assessing Indonesia's Foreign Policy under Joko Widodo. Asia Policy, 25(4), pp. 30-35.

Madu, L. (2015). Indonesia's Foreign Policy under President Joko Widodo: More Domestic and Nationalist Orientations. Southeast Asia, 37(1), pp. 189-197.

Nailufar, N.N. (2017). Misteri Pelemparan Molotov di Kedubes Myanmar [Online]. Tersedia dalam: <https://megapolitan.kompas.com/ $\mathrm{read} / 2017 / 09 / 04 / 09133761 /$ misteri-pelemparan-molotov-di-kedubesmyanmar> [diakses 24 November 2019].

Nuramdani, M. (2017). Aksi Unjuk Rasa Bela Etnis Rohingya Terus Digelar di Berbagai Daerah [Online]. Tersedia dalam: <https://www.liputan6.com/ news/read/3085083/aksi-unjuk-rasa-bela-etnis-rohingya-terus-digelar-diberbagai-daerah> [diakses 24 November 2019].

Nurfuadah, R. N. (2017). Bela Rohingya, Unjuk Rasa Muslim Indonesia di Depan Kedubes Myanmar Disoroti Media Asing [Online]. Tersedia dalam: <https:// news.okezone.com/read/2017/09/04/18/1768842/bela-rohingya-unjuk-rasamuslim-indonesia-di-depan-kedubes-myanmar-disoroti-media-asing > [diakses 24 November 2019].

Perwita, A. A. B. (2017). Agenda dan Tantangan Politik Luar Negeri Bebas Aktif: Sebuah Refleksi Teoretis. Global: Jurnal Politik Internasional, 9(1), pp. 65-74.

Pitsuwan, F. (2014). Smart Power Strategy: Recalibrating Indonesian Foreign Policy. Asian Politics \& Policy, 6(2), pp. 237-266.

Prabandari, A \& Adiputera, Y. (2019). Alternative Paths to Refugee and Asylum Seeker Protection in Malaysia and Indonesia. Asian and Pacific Migration Journal, 28(2), pp. 132-154.

Pramudyani, Y.D. (2019). Langkah Baru ASEAN untuk Membantu Repatriasi Pengungsi Rohingya [Online]. Tersedia dalam: <https://www.antaranews. com/berita/1165028/langkah-baru-asean-untuk-membantu-repatriasipengungsi-rohingya $>$ [diakses pada 29 April 2020].

Purnama, C., et.al. (2019). Indonesia's Role towards Myanmar in Assisting to Resolve the Humanitarian Crisis in Rohingya (2014-2018). Central European Journal of International \& Security Studies, 13(4), pp. 208-222.

Putz, C. (2019). Which Countries are for or Against China's Xinjiang Policies? [Online]. Tersedia dalam: < https://thediplomat.com/2019/07/whichcountries-are-for-or-against-chinas-xinjiang-policies> [diakses 24 November 2019].

Rainer, E., \& Goel, A. (2020). Self-Inflicted Instability: Myanmar and the Interlinkage between Human Rights, Democracy and Global Security. Democracy and Security. DOI: https://doi.org/10.1080/17419166.2020.1811968. 
Rakhmat, M.Z \& Nugroho, A.S. (2019). How Can Indonesia Take Advantage of the Belt and Road's Opportunities? [Online]. Tersedia dalam: <https:// thediplomat.com/2019/03/how-can-indonesia-take-advantage-of-the-beltand-roads-opportunities $>$ [diakses 27 November 2019].

Roberts, C., et.al. (Eds.). (2015). Indonesia's Ascent: Power, Leadership, and the Regional Order. New York: Palgrave Macmillan.

Rosyidin, M. (2017). Foreign policy in Changing Global Politics: Indonesia's Foreign Policy and the Quest for Major Power Status in the Asian Century. South East Asia Research, 25(2), pp. 175-191.

Rosyidin, M. (2020). Reconciling State's Sovereignty with Global Norms: Indonesia's Quiet Diplomacy in Myanmar and the Feasibility of the Implementation of Responsibility to Protect (R2P) in Southeast Asia. Global Responsibility to Protect, 12(1), pp. 11-36.

Rosyidin, M \& Dir, A. A. B. (2020). Why States do not Impose Sanctions: Regional Norms and Indonesia's Diplomatic Approach towards Myanmar on the Rohingya Issue. International Politics. DOI: https://doi.org/10.1057/s41311020-00264-2

Santoso, Y.I. (2019). Berikut 5 Negara dengan Investasi Terbesar di Indonesia [Online]. Tersedia dalam: <https://nasional.kontan.co.id/news/berikut5-negara-dengan-investasi-terbesar-di-indonesia?page=all $>$ [diakses 28 November 2019].

Septiari, D. (2018). China Responds to Indonesia's Question about Alleged Abuse of Xinjiang's Muslims [Online]. Tersedia dalam: <https://www.thejakartapost. com/news/2018/12/20/china-responds-to-indonesias-question-aboutalleged-abuse-of-xinjiangs-muslims.html> [diakses 24 November 2019].

Sari, D.S. (2018). Indonesian Government Policy on Rohingya Refugees. Andalas Journal of International Studies, 7(1), pp. 1-13.

Sriyanto, N. (2018). Global Maritime Fulcrum, Indonesia-China Growing Relations, and Indonesia's Middlepowermanship in the East Asia Region. Jurnal Kajian Wilayah, 9(1), pp. 1-18.

Stuart-Fox, M. (2004). Southeast Asia and China: The Role of History and Culture in Shaping Future Relations. Contemporary Southeast Asia, 26(1), pp. 116-139.

Sukma, R. (2009). Indonesia-China Relations: The Politics of Reengagement. Dalam S. Tang, M. Li, \& A. Acharya (eds.), Living with China, pp. 89-106. New York: Palgrave Macmillan.

The Guardian. (2019). More than 20 Ambassadors Condemn China's Treatment of Uighurs in Xinjiang [Online]. Tersedia dalam: <https://www.theguardian. $\mathrm{com} /$ world/2019/jul/11/more-than-20-ambassadors-condemn-chinastreatment-of-uighurs-in-xinjiang> [diakses 24 November 2019].

Tiezzi, S. (2019). Rival Camps Clash Over Xinjiang at UN Committee Session [Online]. Tersedia dalam: <https://thediplomat.com/2019/10/rival-campsclash-over-xinjiang-at-un-committee-session> [diakses 27 November 2019].

Umagapi, J. L. (2017). The Rise of China-Indonesia Relationship: Soft Power, Resources, and Prospect in the Future. Indonesian Perspective, 2(2). pp. 131142.

UNCTAD. (2019). General Profile: Indonesia [Online]. Tersedia dalam: <http:// unctadstat.unctad.org/countryprofile/generalprofile/en-gb/360/index.html> [diakses pada 29 April 2020].

Viotti, P. R., \& Kauppi, M. V. (2012). International Relations Theory (5th ed.). Boston: Longman. 
Wang, M. (2020). More Evidence of China's Horrific Abuses in Xinjiang but Little Action Holding Beijing Accountable [Online]. Tersedia dalam: <https:// www.hrw.org/news/2020/02/20/more-evidence-chinas-horrific-abusesxinjiang> [diakses 17 Oktober 2020].

Wardah, F. (2018). Demo Protes Kebijakan China terhadap Etnis Muslim Uighur [Online]. Tersedia dalam: <https://www.voaindonesia.com/a/demoprotes-kebijakan-china-terhadap-etnis-uighur/4711859.html> [diakses 24 November 2019].

Wekke, I. S., et.al. (2017). Muslim Minority in Myanmar: A Case Study of Myanmar Government and Rohingya Muslims. Walisongo: Jurnal Penelitian Sosial Keagamaan, 25(2), pp. 303-324.

Wendt, A. (1994). Collective Identity Formation and the International State. American Political Science Review, 88(2), pp. 384-396.

Wendt, A. (1999). Social Theory of International Politics. Cambridge: Cambridge University Press.

Wicaksana, I. G. W. (2019). The Family State: a Non-Realist Approach to Understanding Indonesia's Foreign Policy. Asian Journal of Political Science, 27(3), pp. 308-328. 